\title{
NON-ENGLISH MAJORS' PERCEPTIONS AND USE OF METACOGNITIVE STRATEGIES AT A VIETNAMESE EFL CONTEXT
}

\author{
Vo Thi Tu Trinh ${ }^{1}$ Duong My Tham ${ }^{2 *}$ \\ ${ }^{1}$ Ho Chi Minh City Open University \\ ${ }^{2}$ Ho Chi Minh City Nong Lam University
}

\section{ABSTRACT}

The present study aimed to first investigate how non-English majored juniors at a Ho Chi Minh Citybased college perceived the importance of metacognitive strategies and to what extent they used these strategies and then explore significant differences between their perceptions and use of metacognitive strategies. The mixed-methods study was conducted with the participation of 342 non-English majored juniors at the college. The quantitative data collected from the questionnaire were processed by SPSS (26.0), whereas content analysis was employed to analyze the qualitative data obtained from the semistructured interview. The findings generally revealed that metacognitive strategies were believed to be significant by a large number of the students. In terms of their employment of metacognitive strategies, only some strategies relating to goal setting, needs-based adjustments, and reflections were employed frequently by most of the participants. Moreover, the study also indicated some significant differences between the learners' perceptions and their actual use of metacognitive strategies. Based upon the aforementioned findings, some recommendations for further research on autonomous language learning strategies with a focus on metacognitive strategies are made.

Keywords: Metacognitive strategies; autonomous language learning strategies; non-English majors; at college level; Vietnamese EFL context

Received: 16/10/2020; Revised: 26/10/2020 ; Published: 30/10/2020

\section{NHẬN THỨC VÀ THỬC TRẠNG SỬ DỤNG CHIẾN LƯợC SIÊU NHẬN THÚC CỦA SINH VIỂN KHỒNG CHUY்ÊN NGỮ TAI MỘT BỐI CẢNH DẠY TIẾNG ANH NHU NGOẠI NGŨ Ở VIỆT NAM}

\author{
Võ Thị Tú Trinh ${ }^{1}$, Dương Mỹ Thẩm* \\ ${ }^{1}$ Trường Đại học Mờ Thành phố Hồ Chí Minh \\ ${ }^{2}$ Truò̀ng Đại học Nông Lâm Thành phố Hồ Chỉ Minh
}

\section{TÓM TẮT}

Nghiên cứu này được thực hiện nhằm tìm hiểu nhận thức của sinh viên năm thứ ba không chuyên ngữ tại một trường cao đẳng ở thành phố Hồ Chí Minh về tầm quan trọng của chiến lược siêu nhận thức cũng như mức độ áp dụng chiến lược siêu nhận thức của những sinh viên này. Ngoài ra, nghiên cứu còn xem xét sự khác biệt giữa 2 yếu tố này. Nghiên cứu được thực hiện với sự tham gia của 342 sinh viên. Dữ liệu định lượng thu được từ bảng hỏi được phân tích bằng phần mềm thống kê phân tích SPSS (26.0). Bên cạnh đó, phương pháp phân tích nội dung được sử dụng để phân tích dữ liệu định tính thu thập từ phỏng vấn bán cấu trúc. Kết quả phân tích cho thấy rằng, đa số đối tượng khảo sát nhận thấy tầm quan trọng của các chiến lược siêu nhận thức đối với việc học tiếng Anh của mình; họ sử dụng những chiến lược siêu nhận thức liên quan đến việc lập mục tiêu học tập, điều chỉnh nội dung học theo nhu cầu bản thân và phản ánh lại những gì đã học một cách khá thường xuyên; có sự khác biệt đáng kể giữa nhận thức và việc sử dụng các chiến lược siêu nhận thức của những sinh viên này. Trên cơ sở những kết quả tìm được của nghiên cứu này, các nghiên cứu sau có thể tìm hiểu sâu hơn về chiến lược tự học, đặc biệt là chiến lược siêu nhận thức. Từ khóa: Chiến luợc siêu nhận thức; chiến luợc tư học; sinh viên không chuyên ngũ ; bậc cao đẳng; bối cảnh học tiếng Anh nhu một ngoại ngữ tại Việt Nam

Ngày nhận bài: 16/10/2020; Ngày hoàn thiện: 26/10/2020; Ngày đăng: 30/10/2020

* Corresponding author. Email: duongmythamav@yahoo.com

DOI: https://doi.org/10.34238/tnu-jst.3703 


\section{Introduction}

Language learning strategies (LLSs) are a series of tools such as specific actions, behaviors, steps or techniques that students often intentionally employ to improve their learning progress in second language acquisition and to learn a new language more effectively [1]. In addition, Williams and Burden [2] affirmed that learning strategies are a variety of operations taken by learners in order to make sense of their learning. From the definitions of LLSs, it is inferred that autonomous language learning strategies (ALLSs) in the broader sense or selfregulated language learning strategies in its narrower one refer to the strategies that help language learners take active roles in their learning and assist them to become autonomous learners [3]. The core of ALLSs is self-exploration, self-discovery, which focus is how to help students learn the language and skills [4]. Of the type of ALLSs, metacognitive strategies are one kind of behavior that students manage, monitor and evaluate learning process by themselves [1].

In the 21 st century, the concept of learner autonomy is supposed to be crucial within the changing landscape of English teaching, and advocates of learner autonomy believe that it plays an important role for life-long learning [5]. Despite the significance and familiarity of learner autonomy to learners, students' use of this concept are, nevertheless, constrained to some extent due to teacher-centered approaches, exam-oriented education, especially the lack of the most important factor - effective ALLSs in general and metacognitive strategies in particular. Consequently, in order to train students to be autonomous learners, apart from the necessity of raising learners' awareness of the importance of ALLSs in language learning because "the beliefs and attitudes learners hold have a profound influence on their learning behavior" [6, p. 195], their practices which means their implementation of ALLSs should also be taken into consideration. According to Williams and Burden [7], being autonomous means that learners themselves can find their own ways of self-study, and only learning strategies can be the answer for this problem. Moreover, Li [8] stated apart from stimulating students' learning initiative and enthusiasm effectively, ALLSs can also improve their autonomous learning ability and learning efficiency. In order to highlight the significance of ALLSs, Zhao [4] listed three beneficial aspects of ALLSs regarding improving students' learning and learning efficiency on a large scope, guiding teachers' teaching methodology more effectively, and being useful to new curriculum reform. More specifically, thanks to the support of ALLSs in reducing learning disabilities and in increasing self-confidence in learning, students' learning and learning efficiency can be enhanced. Besides, objective and meaningful ALLSs facilitate teachers' teaching by decreasing the teaching and training time, which in its turn, releasing the burden of students' learning. Finally, grasping the strategy of knowledge acquisition contributes to grasp more knowledge. To conclude, Chamot and Kupper (cited in [9]) revealed successful students use their learning strategies more often, more efficient, and varied. In contrast, the less successful students have fewer and even less applicable learning strategies.

However, there have been no studies on students' perceptions and use of ALLSs, particularly metacognitive strategies, conducted at the research setting so far. Moreover, although learners have positive attitudes towards learner autonomy, their practices are limited to a great extent. Nevertheless, few studies have been administrated to identify the differences between these two elements in foreign and Vietnamese contexts. Some of the previous 
studies were concerned with the perceptions and practices of teachers (e.g. [10], [11], [12]). This is regarded a big gap that needs to be fulfilled. Therefore, this paper aims to explore the perceptions of non-English majored students at the college regarding the importance of metacognitive strategies, to identify the extent to which they think they can use metacognitive strategies, and lastly to identify the differences between the nonEnglish majors' perceptions and their use of metacognitive strategies. Accordingly, three research questions are formulated as follows.

1. What are the non-English majors' perceptions of the importance of metacognitive strategies in English language learning?

2. To what extent do the non-English majors employ metacognitive strategies?

3. Are there any significant differences between the non-English majors' perceptions and their use of metacognitive strategies? If so, how?

\section{Methodology}

\subsection{Participants}

The study recruited 342 non-English majored juniors taking the course of English for Business Communication 2 at the college with the support of random sampling technique. Turning to details, there were 39 males (11.4\%) and 303 females (66.6\%). Most of them were at the age of $21(86.3 \%)$. Regarding years of learning English, 60.5\% of them have spent 5-10 years learning English, whereas the figures for doing so for more than 10 years and less than 5 years were $29.5 \%$ and $9.9 \%$ respectively.

\subsection{Research design}

This study employed a mixed-methods design to collect sufficient data for the research question. In specific, the author obtained the quantitative data from the questionnaire and qualitative data from the semi-structured interview. By reason, Fraenkel \& Wallen [13] stated that a research problem and a target phenomenon would be comprehended more completely with the support of mixedmethods than either method alone. Likewise, Johnson and Christensen [14] pinpointed that both methods can complement each other when they are concurrently or sequentially (one part first and the other second) employed in a study to answer a research question.

\subsection{Research instruments}

The researcher decided to utilize a questionnaire which is known to be one of the easiest methods to manage, even with large numbers of subjects [15] and one of the most useful tools to exploit the subjects' attitudes, beliefs and perceptions [16]. The first section of the questionnaire focused on information about students' gender, age, years of English learning. The second section was divided into two parts: The first part focusing on learners' perceptions of the importance of metacognitive strategies had 6 items in the form of the five-point Likert scale ranging from not at all important to very important; the second part aiming to explore the learners' use of metacognitive strategies also had 6 items in the form of the five-point Likert scale: Never, Seldom, Sometimes, Often to Always. To ensure the reliability of the questionnaire, it was translated into Vietnamese so that the respondents did not have any difficulties in understanding the questionnaire items. Furthermore, the Cronbach's alpha values of the perceptions and the use of metacognitive strategies are .81 and .87 respectively, which indicates that the reliability of the questionnaire is very high.

Apart from the questionnaire, the author employed a semi-structured interview because "the interviewer can clarify any questions that are obscure and also can ask the respondent to expand on answers that are particularly important or revealing" [13, p. 119], thus making it possible to investigate the target 
phenomenon in greater depth and breadth [17]. In addition to administering the questionnaire, individual interviews were conducted with 15 students to investigate their perceptions and actual use of metacognitive strategies in language learning at the college.

\subsection{Data collection and analysis}

The questionnaire was first administered to 342 participants, and the researchers found that all 342 copies $(100 \%)$ were valid and accepted for analysis. Then, the researcher employed Statistical Package for the Social Sciences (SPSS) version 26.0 to analyze the descriptive statistics of the collected questionnaires in terms of Mean (M), Standard deviation (SD), and Paired samples $\mathrm{t}$-test. The score interval for mean scores is interpreted as follows: $1.00-1.80$ : Not at all important/ Never; 1.81 - 2.60: Not very important/ Seldom; 2.61 - 3.40: Soso/Sometimes; 3.41 - 4.20: Important/Often; 4.21 - 5.00: Very important/Always.

After the questionnaire treatment, the researchers invited 15 members from the target sample to participate in the individual interviews. The interviews were conducted in the Vietnamese language using a set of semistructured questions to ask and a tape recorder to record the interviewees' answers. Afterwards, the researcher transcribed and translated the transcripts into English for analysis. Finally, the researchers organized the transcribed and translated interview into three main pre-determined themes, including (1) non-English majors' perceptions of the importance of metacognitive strategies, (2) their use of metacognitive strategies, and (3) the significant differences between nonEnglish majors' perceptions and their use of metacognitive strategies. The interviewees were labeled from S1 to S15.

\section{Results and discussion}

\subsection{Results}

3.1.1 Non-English majors' perceptions of the importance of metacognitive strategies

Table 1 shows that all strategies in this group were thought to be crucial by the respondents indicated through the high mean score of 3.71 and the standard deviation of .63. To be more specific, among six items, the strategy of setting the target for my English study and determining to achieve it was regarded as the most significant one (Item $1, \mathrm{M}=4.09, \mathrm{SD}=.80$ ), followed by the strategies of "I change my learning content and target according to my needs" (Item 3, M = 3.70, SD = .84); "I reflect on what I have learned based on my learning goals" (Item $6, \mathrm{M}=3.68, \mathrm{SD}=.90$ ); "I carry out the learning plans once they have been made" (Item $2, \mathrm{M}=3.65, \mathrm{SD}=.86$ ); "I select criteria to evaluate my learning outcome" (Item 5, M = 3.59, SD = .90); and "I monitor whether my learning is progressing according to my plan" (Item 4, $\mathrm{M}=3.53, \mathrm{SD}=.96$ ).

Table 1. Non-English majors' perceptions of the importance of metacognitive strategies

\begin{tabular}{clccc}
\hline \multirow{2}{*}{ Item } & Metacognitive Strategies & \multirow{2}{*}{ Rank } & \multicolumn{2}{c}{$\mathbf{n}=\mathbf{3 4 2}$} \\
\cline { 3 - 5 } & & $\mathbf{M}$ & SD \\
\hline 1 & I set the target for my English study and determine to achieve it. & 1 & 4.09 & .80 \\
2 & I carry out the learning plans once they have been made. & 4 & 3.65 & .86 \\
3 & I change my learning content and target according to my needs. & 2 & 3.70 & .84 \\
4 & I monitor whether my learning is progressing according to my plan. & 6 & 3.53 & .96 \\
5 & I select criteria to evaluate my learning outcome. & 5 & 3.59 & .90 \\
6 & I reflect on what I have learned based on my learning goals. & 3 & 3.68 & .90 \\
& Average & & $\mathbf{3 . 7 1}$ & $\mathbf{. 6 3}$ \\
\hline
\end{tabular}


Similarly, most of the interviewees reported that the setting of the target for their English study and determining to achieve it are important. Next, the change of their learning content and target according to their needs were also revealed by a large number of them. In addition, many interviewees stated that it was necessary to reflect on what they have learned based on their learning goals and carry out the learning plans once they have been made. Finally, as perceived by a few students, they should select criteria to evaluate their learning outcome and monitor whether their learning is progressing according to their plan.

For me, the setting up of the target for English study and determining to achieve it is really essential since it gives me more efforts and encouragements to fulfil my targets. (S1)

If I can complete the learning plans once they have been made, I will feel happy and satisfied which in its turn, helps me keep on trying and moving forwards in English learning. (S5)

Monitoring whether my learning is progressing according to my plan and reflecting on what I have learned based on my learning goals are significant in that they help me keep track of my learning frequently, therefore having timely adjustments to get the best learning results. (S10)

\subsubsection{Non-English majors' use of metacognitive strategies}

As can be observed from Table 2, the total mean score of the whole group was pretty high $(\mathrm{M}=3.42, \mathrm{SD}=.72)$ which indicated that the students employed metacognitive strategies at a high frequency. However, when taking a more thorough look at every single item in this group, it can be seen that Items 1 , 3 , and 6 had high mean values while Items 2 , 4 and 5 had lower mean indexes. More specifically, by the highest mean score $(\mathrm{M}=$ 3.63, $\mathrm{SD}=0.92$ ), the descriptive statistics of Item 1 revealed that the large number of the participants frequently set the target for their English study and determine to achieve it. Being ranked at the second highest position with the mean score of 3.46 and the accompanied standard deviation of .89 , Item 3 showed that most of the respondents selfassessed that they often change their learning content and target according to their needs. Similarly, the reflection on what they have learned based on their learning goals were also employed repeatedly by the majority of the respondents (Item 6, M= 3.45, $\mathrm{SD}=.89$ ).

Concerning the remaining strategies with average mean scores, Item $2(\mathrm{M}=3.32, \mathrm{SD}=$ .93) showed that the participants carry out the learning plans once they have been made now and then. Being nearly consistent to Item 2 with the mean index of 3.33 and the standard deviation of .97 , Item 5 revealed that the participants select criteria to evaluate their learning outcome from time to time. Finally, by the lowest mean score in this group $(\mathrm{M}=$ $3.29, \mathrm{SD}=.95$ ), Item 4 showed that the strategy of monitoring whether my learning is progressing according to my plan were occasionally used by the response community.

Table 2. Non-English majors' use of metacognitive strategies

\begin{tabular}{clccc}
\hline \multirow{2}{*}{ Item } & Metacognitive Strategies & \multirow{2}{*}{ Rank } & \multicolumn{2}{c}{ n = 342 } \\
\cline { 3 - 5 } & & M & SD \\
\hline 1 & I set the target for my English study and determine to achieve it. & 1 & 3.63 & .92 \\
2 & I carry out the learning plans once they have been made. & 5 & 3.32 & .93 \\
3 & I change my learning content and target according to my needs. & 2 & 3.46 & .89 \\
4 & I monitor whether my learning is progressing according to my plan. & 6 & 3.29 & .95 \\
5 & I select criteria to evaluate my learning outcome. & 4 & 3.33 & .97 \\
6 & I reflect what I have learned based on my learning goals. & 3 & 3.45 & .89 \\
& Average & & $\mathbf{3 . 4 2}$ & $\mathbf{. 7 2}$ \\
\hline
\end{tabular}

http://jst.tnu.edu.vn; Email: jst@tnu.edu.vn 
Qualitatively, when the researchers asked "How often do you employ metacognitive strategies? Specify your response", a large number of the participants revealed that they "usually" set the target for their English study, change their learning content and target according to their needs, and reflect on what they have learned based on their learning goals. However, the respondents did not often use the remaining strategies in this group. More specifically, the strategies of selecting criteria to evaluate my learning outcome, of carrying out the learning plans once they have been made, and of monitoring whether my learning is progressing according to my plan were sometimes utilized by many of them.

I often set the target for my English study in that if I do this, I will have more motivation to keep on trying to achieve my goals, which in its turn, improve my level of English proficiency. (S1)

I change what I learn and my target according to my needs regularly because if the content and targets fix my needs, I will find it more interesting to study. (S14)

Reflecting on what I have learned based on my learning goals is the thing that I often do in order to keep track of my learning frequently. (S15)

3.1.3 The significant differences between nonEnglish majors' perceptions and use of metacognitive strategies

Statistically, there was a significant difference between the participants' perceptions and their use of metacognitive strategies in terms of mean scores $(\mathrm{p}=.000<.01)$. This means that the respondents thought that metacognitive strategies were important to their English language learning. Their use of these strategies was divided into two groups in which group 1 included three items which were frequently used by the participants (Item $1, \mathrm{M}=3.63, \mathrm{SD}=.92 ;$ Item $3, \mathrm{M}=3.46, \mathrm{SD}$ $=.89$; Item $6, \mathrm{M}=3.45, \mathrm{SD}=.89$ ) and group
2 involved three remaining items which were sometimes utilized by the students (Item 2, M $=3.32, \mathrm{SD}=.93$; Item $4, \mathrm{M}=3.29, \mathrm{SD}=.95$; Item $5, \mathrm{M}=3.33, \mathrm{SD}=.97$ ).

\subsection{Discussion}

This study has revealed some significant findings. It was, firstly, seen that the nonEnglish majors at the research context believed that metacognitive strategies played an important role in their English language learning. They thought that it is crucial to set the target for their English study and determine to achieve it, to carry out the learning plans once they have been made, to change their learning content and target according to their needs, to monitor whether their learning is progressing according to their plan, and to reflect on what they have learned based on their learning goals. The findings are consistent with those in the previous studies [1], [7], [8].

Additionally, the results indicated that the respondents used metacognitive strategies at a high frequency. Specifically, the participants showed the frequent utilization in (1) setting the target for their English learning and determining to achieve it, (2) shifting their learning content and learning target according to their needs, and (3) conducting reflection on what they have learned based on their learning goals. Nevertheless, the strategies of conducting the learning plans once they have been made; of monitoring whether my learning is progressing according to my plan; and of selecting criteria to evaluate my learning outcome were not utilized repeatedly by most students. In contrast, Duong [18] discovered that English majors tended to use more metacognitive strategies associated with critical thinking and monitoring than metacognitive strategies of goal setting.

Finally, there were significant differences between the students' perceptions and their use of metacognitive strategies. These 
dissimilarities revealed two possibilities: Some items in the group of metacognitive strategies were thought to be crucial by most participants, thus being frequently employed by them, and despite the importance, the remaining strategies still were not utilized regularly since the students encounter certain barriers when employing them. To be specific, even if all items in the group of metacognitive strategy received significant to the participants, only three of them were utilized frequently which are "I set the target for my English study and determine to achieve it", "I change my learning content and target according to my needs", and "I reflect on what I have learned based on my learning goals". In contrast, the respondents practiced the strategies of conducting the learning plans once they have been made, monitoring whether their learning is progressing according to their plan, and selecting criteria to evaluate their learning outcome at an average level because of the discouragement they have experienced when they cannot complete their plans and the lack of suitable rubrics or approaches to monitor or evaluate their learning outcome, respectively.

\section{Conclusion}

Since the non-English majors perceived the importance of metacognitive strategies in ELL, they used some strategies in this group quite frequently. Regardless of the high use of the metacognitive strategies involving setting goals, adjusting learning content in alignment with learners' needs, and making reflections, the respondents sometimes employed the strategies of selecting criteria for evaluation, conducting learning plans, and monitoring their learning process. In addition, some significant differences between the participants' perceptions and use of metacognitive strategies were explored.

Some pedagogical implications are withdrawn from the results. Firstly, based on the non-
English majors' high perceptions of the importance of LA in ELL, it is imperative that non-English majors should be informed of the importance of using ALLSs, specifically metacognitive strategies in ELL so that they should get prepared for life-long learning since one of the skills for 21 st century learners is being able to act independently. If they want to become successful language learners, they should allocate more time on independent language learning. Next, it is challenging for the students to self-evaluate or self-monitor their learning outcomes if they do not know how to do it effectively. For that reason, it is suggested by the study that teachers should help the students by introducing some kinds of rubrics for selfevaluation to students. Moreover, teachers should also instruct the students how to selfmonitor their learning outcomes efficiently.

\section{REFERENCES}

[1]. R. L. Oxford, Language learning strategies: What every teacher should know. Boston: Heinle \& Heinle Publishers, 1990.

[2]. M. Williams and R. Burden, Psychology for language teachers. Cambridge: Cambridge University Press, 1997.

[3]. Z. Dörnyei, Questionnaires in second language research: Construction, administration, and processing. Mahwah, $\mathrm{NJ}$ : Lawrence Erlbaum, 2003.

[4]. W. Zhao, "Research on college English autonomous learning strategies based on the digital instructional platform," Theory \& Practice in Language Studies, vol. 4, no. 9, pp.1918-1923, 2014.

[5]. T. M. Duong, "Portfolio-based learner autonomy development model in an EFL writing course," PhD. Thesis, Suranaree University of Technology, Nakhon Ratchasima, Thailand, 2016.

[6]. S. Cotterall, "Developing a course strategy for learner autonomy," ELT Journal, vol. 49, no. 3, pp. 219-227, 2016.

[7]. M. Williams and R. Burden, Psychology for language teachers. Cambridge: Cambridge University Press, 1997.

[8]. B. Li, "Study on English learning strategies and autonomous learning ability," Hubei Today, vol. 2, pp. 65-72, 2007. 
[9]. S. K. McDonough, "Promoting self-regulation in foreign language learners," The Clearing House, vol. 74, no. 6, pp. 323-326, 2001.

[10]. A. A. Asmari, "Practices and prospects of learner autonomy: Teachers' perceptions," English Language Teaching, vol. 6, no. 3, PP. 1-10, 2013.

[11]. G. Doğan and İ. H. Mirici, "EFL instructors' perception and practices on learner autonomy in some Turkish universities," Journal of Language and Linguistic Studies, vol. 13, no. 1, pp. 166-193, 2017.

[12]. T. M. Duong, "EFL teachers' perceptions of learner autonomy and their classroom practices: A case study," IJ Education and Management Engineering, vol. 2, pp. 9-17, 2014.

[13]. J. R. Fraenkel and N. E. Wallen, How to design and evaluate in education, $7^{\text {th }}$ ed. New York: McGraw-hill, 2009.
[14]. B. Johnson and L. Christensen, Educational research: Quantitative, qualitative, and mixed Approaches. California: Sage Publications, 2012.

[15]. Z. Dörnyei, Questionnaires in second language research: Construction, administration, and processing, $2^{\text {nd }}$ ed. London: Routledge, 2010.

[16]. V. Koshy, Action research for improving practice: A practical guide. London: PCP/Sage Publications, 2005.

[17]. C. O'Hanlon, Educational inclusion as action research: An interpretive discourse. Buckingham: Open University Press, 2003.

[18]. T. M. Duong, "First-year English Majors' Use of Autonomous Learning Strategies," (in Vietnamese), VNU Journal of Science: Education Research, vol. 36, no. 3, pp. 5260, 2020. 